\title{
THE EFFICIENCY OF PROTEIN UTILIZATION IN DIFFERENT BROILER STRAINS
}

\author{
B. Indarsih ${ }^{1}$ and R.A.E. Pym ${ }^{2}$ \\ ${ }^{1}$ Faculty of Animal Science, University of Mataram, NTB - Indonesia \\ ${ }^{2}$ School of Veterinary Science, University of Queensland, Australia \\ Corresponding E-mail:budiindarsih@gmail.com
}

Received June 16, 2009; Accepted August 28, 2009

\begin{abstract}
The objective of this work was to study the protein utilization and protein turnover of different broiler strains and was carried out in completely randomized design. One hundred and forty four sexed doc from each strain $($ Cobb $=\mathrm{A}$, Ingham $=\mathrm{B}$ and Steggels $=\mathrm{C}$ ) were divided into a factorial arrangement (three dietary protein, two sexes and three strains). Two regimens of composite mixes of a summit and dilution diet and a free choice between these two diets. Diets were changed weekly, with notional crude protein levels at one day-old of $240 \mathrm{~g} / \mathrm{kg}$ for all chickens, and at 42 days of age of 120 or $180 \mathrm{~g} / \mathrm{kg}$ in the low and high protein. Protein utilization efficiency (PRE) was measured from 39-42 d of age. PRE increased with the increasing of dietary protein in strains $\mathrm{A}$ and $\mathrm{C}$ and had much higher response than in strain $\mathrm{B}$. The moisture: protein ratios were 2.51, 2.65 and 2.58 in strains A, B and C, indicating strain B contained higher moisture and body fat and less protein. Involvement of genetic controls as the selection effect seems to increase the capacity of chickens in improving nutrient utilization.
\end{abstract}

Keywords: Summit Dilution, Strains, Protein

\section{INTRODUCTION}

Dietary protein quality is an important factor influencing the efficiency of protein used for production parameters (Urdaneta- Rincon and Leeson, 2004) and growth is the main indicator to measure these parameters. Growth is a net increase of protein mass and it will occur when proteins are degraded and the total protein synthesis must also exceed net protein gain. This continuing process is referred to protein turnover and the rate of growth is determined by the balance between the rates of synthesis and breakdown. Efficiency of protein utilization is influenced by the changes in the rates of both synthesis and degradation (Tesseraud, 2000), but the critical determinant of net protein utilization efficiency is the rate of degradation (Buttery, 1981; Tomas et al., 1988).

Degradation rates are increased by amino acid deficiency (Sunde et al., 1984; Nieto et al., 1995), which is the main reason that amino acid balance must be optimal to maximize both protein utilization efficiency and growth performance. UrdanetaRincon and Leeson (2004) have shown that the increasing of fractional rate of protein synthesis (FSR) parallel with the increasing of diet lysine levels at 290 $\mathrm{g}$ of $\mathrm{CP} / \mathrm{kg}$. For fast growing broiler chicks, lysine deficiency have changed body composition and protein synthesis (Ojano-Dirain and Waldroup, 2002; Bastianelli et al., 2007). It means that to support optimum growth and carcass yield of fast- growing commercial broilers, adequate dietary levels of amino acids are needed.

Strain differences in growth rate have been shown to be the result of variation in the efficiency of protein utilization (Kang et al., 1985) and the growth rate differences between broilers and layers have been shown to be due to a lower rate of protein degradation in broilers than in layers (Hayashi et al., 1985; Rosa et al, 2001a; Rosa et al., 2001b). Tomas et al. (1988) suggested that selection has been done to improve feed utilization efficiency in oeder to reduce the rate of skeletal muscle protein degradation as measured by 3-methyl histidine excretion, whilst selection to 
increase growth rate or to reduce body fatness have been shown increasing gross protein utilization efficiency (Geraert et al., 1987; McLeod et al., 1988, Tomas and Pym, 1995). Differences in growth performance and nutrient utilization between commercial strains of broilers, may be due to the differences in protein utilization efficiency and genetic differences influence the response of chicks to varying dietary level of crude protein (Ojano-Dirain and Waldroup, 2002; Sterling et al., 2003; Sterling et al., 2006; Bastianelli et al., 2007). Derivative of the amino acid, and histidine nare found mainly in the contractile proteins of muscle (myosin and actin). Compared to other purposes, it is useful that 3-methyl histidine as an index of lean meat content of prepared foods, since it is not present in collagen or other added materials.

The purpose of the present study was to determine protein utilization and protein turnover of a number of strains of broiler chickens.

\section{MATERIALS AND METHODS}

\section{a. Chickens and experimental procedure}

One hundred and forty four sexed day-old chicks from each of the 3 strains $(\mathrm{Cobb}=\mathrm{A}$, Ingham $=\mathrm{B}$ and Steggles $=$ C) were designed comprised 3 strains, 2 sexes and 3 dietary treatments in a factorial design with 3 replicates each of approximately 8 chickens. They were then weighed at one-d-old and reared in the 54 brooder cage $1.0 \mathrm{~m} \times 1.0 \mathrm{~m}$. Each cage was equipped with one drinker and 1 circular tube feeder. Temperature of the experimental house was maintained at about $32^{\circ} \mathrm{C}$ for week $1,29^{\circ} \mathrm{C}$ for week $2,26^{\circ} \mathrm{C}$ for week 3 , and $22^{\circ} \mathrm{C}$ thereafter.

\section{b. Dietary treatments and feeding programs}

A summit-dilution approach was used in many of the studies in diet formulation to examine the growth and body composition responses of different strains to variety of dietary amino acid concentration (Gous and Morris, 1985; Surisdiarto and Farrell, 1991; Huyghebaert and Pack, 1996; Plumstead et al., 2007). The summit diet was formulated to contain a large excess of assume requirement of all indispensable amino acids except the one under the test, which was set up around $145 \%$ of the assume requirement (Gous and Morris, 1985). The advance of this approach using a dilution diet is that food intake of this diet is not affected by dietary imbalance or deficiencies of a specific amino acid (Emmans, 1987).

The three dietary regimens comprised of two regimens of composite mixes of a summit and dilution diet and were changed weekly, with notional crude protein levels at one day-old of $240 \mathrm{~g} / \mathrm{kg}$ for all chickens, and at 42 days of age of 120 or $180 \mathrm{~g} / \mathrm{kg}$ in the low and high protein regimens respectively. The third was a free choice between the summit and dilution diets.

All chickens with the exception of the choice fed group were given summit diet 1 (Table 1) containing $257 \mathrm{~g} \mathrm{CP}$ (Crude Protein) and $3100 \mathrm{Kcal}$ ME (Metabolizable Energy) per kg, from hatch to 5 days of age. The choice-fed birds were then given both the summit and dilution diets in divided feeders after being individually weighed and then assigned to their experimental treatment groups.

At 21 days, 234 chickens were transferred into individual cages with 13 single-bird replicates for each treatment and were given diets constituted from the zero animal protein summit 2 and/or the dilution diet (Table 1). Because of the lower protein in summit 2 compared to summit 1, there was a significant increase in the inclusion rate of the former diet from $21 \mathrm{~d}$. These diets were utilised to allow calculation of protein turnover rates determined by 3-methyl histidine excretion as a measure of myofibrillar breakdown (Young and Munro, 1978). This method is also used to indicate the total muscle mass (Buttery, 1981).

\section{c. Measurements}

Measurements were made of growth rate, body composition and protein turnover. Weight gain and food intake was measured at weekly basis till 42 days of age. Body composition was observed at $42 \mathrm{~d}$ of age using all samples of 5 chickens from each dietary treatment and were slaughtered after being fasted for $12 \mathrm{~h}$ before being killed by cervical dislocation and then stored at $-20^{\circ} \mathrm{C}$ for further analysis. Chemical analysis of the carcass samples is carried out according to Pym and Solvyns (1979) which have been modified.

Protein turnover was measured by calculating food intake and body weight, and collecting excreta production on daily basis of each bird from 39 to 42 $\mathrm{d}$ of age. After collection, the three-days samples of 
Table 1. Ingredient and Determined Nutrient Composition $(\mathrm{g} / \mathrm{kg})$ of The Summit and Dilution Diets Used In The Preparation of Composite Diets Given to The Three Strains of Chickens In The Protein Utilization Study.

\begin{tabular}{lccr}
\hline & Summit 1 & Summit 2 & Dilution \\
\hline Ingredients & & & \\
Sorghum 9\% & 600.9 & 580.9 & 707.8 \\
Sunflower oil & 15.4 & 34.5 & 24.3 \\
Limestone & 1.9 & 13.6 & 17.8 \\
Fish meal 65\% & 75.0 & - & - \\
Meat mea1 50\% & 50.5 & - & - \\
Soybean 47 \% (solvent) & 250.0 & 344.7 & 88.5 \\
Wheat 13\% & - & - & 100.0 \\
Rice hull fraction & - & - & 39.9 \\
Threonine & 0.80 & 0.63 & 0.02 \\
DL Methionine & 1.68 & 2.04 & 0.53 \\
Lysine & 16.45 & 11.64 & 8.02 \\
Methionine & 5.00 & 4.25 & 2.45 \\
Methionine plus cysteine & 8.30 & 7.23 & 4.70 \\
Isoleucine & 8.62 & 7.19 & 3.58 \\
Leucine & 20.17 & 16.21 & 12.47 \\
Threonine & 5.23 & 7.43 & 6.02 \\
Tryptophan & 3.93 & 3.34 & 2.36 \\
Calcium* & 10.0 & 10.0 & 10.0 \\
Phosphorus (available)* & 6.0 & 4.5 & 5.0 \\
Nutrients & & & \\
M.E. (Kcal/kg)* & 3100 & 3100 & 3100 \\
Crude Protein & 257.20 & 197.90 & 146.40 \\
Lysine & 16.45 & 11.64 & 8.02 \\
Methionine & 5.00 & 4.25 & 2.45 \\
Methionine plus cysteine & 8.30 & 7.23 & 4.70 \\
Isoleucine & 8.62 & 7.19 & 3.58 \\
Leucine & 20.17 & 16.21 & 12.47 \\
Threonine & 5.23 & 7.43 & 6.02 \\
Tryptophan & 3.93 & 3.34 & 2.36 \\
Calcium* & 10.0 & 10.0 & 10.0 \\
Phosphorus (available)* & 6.0 & 4.5 & 5.0 \\
\hline * Calulat value & &
\end{tabular}

excreta from each bird was stored at $-20^{\circ} \mathrm{C}$ for analysis of moisture, nitrogen and 3-methyl histidine. Nitrogen retention was determined in the chickens from measurement of food intake, analyses of carcass composition and weight gain over the period (Farrell, 1974). Protein retention efficiency (PRE) was calculated as follows

$\operatorname{PRE} \%=\%$ carcass protein $\mathrm{X} 3 \mathrm{~d}$ weight gain $(\mathrm{g})$ $3 \mathrm{~d}$ dietary protein intake $(\mathrm{g})$

\section{d. Statistical Analysis.}

Data were analysed according to the General Linear Model using SAS (version 6.07) (SAS., 1996). The major independent variables were strain, sex and diet. Statistical significance among the treatments means were compared using the Least Significant Difference (LSD) test $(\mathrm{P}<0.05) \quad$ (Kaps and Lamberson, 2004).

\section{RESULTS AND DISCUSSION}

The food intake, FCR, protein intake and 42-d body weight are shown in Table 2 . There were significant $(\mathrm{P}<0.05)$ effects of strain, sex and diet, however, thre was no significant interaction between the main effect for these parameters. Males had higher feed consumption and protein intake which better FCR than females. Strain A and B consumed more food and protein than strain C, but strain B were, more efficient in FCR. Food intake decreased in high dietary protein and was the lowest in the free choice 
Table 2. Food Intake $(\mathrm{g} / \mathrm{d})$, FCR $(\mathrm{g} / \mathrm{g})$ and Protein Intake $(\mathrm{g} / \mathrm{d})$ of Three Commercial Strains from $\mathrm{d} 35$ to 42 Subjected to Three Nutritional Regimen and Mean 42 d Body Weight (g)

\begin{tabular}{lcccc}
\hline \multicolumn{1}{c}{ Variable } & Food Intake & FCR & Protein Intake & Body weight \\
\hline Sex & & & & \\
Male & $141^{\mathrm{a}}$ & $2.428^{\mathrm{b}}$ & $14.79^{\mathrm{a}}$ & $2031^{\mathrm{a}}$ \\
Female & $124^{\mathrm{b}}$ & $2.784^{\mathrm{a}}$ & $12.92^{\mathrm{b}}$ & $1840^{\mathrm{b}}$ \\
Strain & & & & \\
A & $139^{\mathrm{a}}$ & $2.714^{\mathrm{a}}$ & $14.51^{\mathrm{a}}$ & $1959^{\mathrm{a}}$ \\
B & $135^{\mathrm{a}}$ & $2.457^{\mathrm{b}}$ & $14.23^{\mathrm{a}}$ & $1975^{\mathrm{a}}$ \\
C & $123^{\mathrm{b}}$ & $2.648^{\mathrm{a}}$ & $12.84^{\mathrm{b}}$ & $1875^{\mathrm{b}}$ \\
Diet & & & & \\
120 & $139^{\mathrm{a}}$ & $2.901^{\mathrm{a}}$ & 13.47 & $1906^{\mathrm{b}}$ \\
180 & $130^{\mathrm{b}}$ & $2.344^{\mathrm{c}}$ & 14.47 & $2007^{\mathrm{a}}$ \\
Choice & $126^{\mathrm{c}}$ & $2.574^{\mathrm{b}}$ & 13.64 & $1893^{\mathrm{b}}$ \\
LSD0.05 & 4 & 0.210 & 1.32 & 83 \\
\hline
\end{tabular}

Main effects significant $(\mathrm{P}<0.05)$. Interaction not significant $(\mathrm{P}>0.05)$

Means within different series with different superscripts, are significantly different $(\mathrm{P}<0.05)$

fed groups, but there was no differences significant in dietary protein intake among the three dietary regimens. FCR was better in high dietary protein, while the choice fed birds in intermediate. Males were heavier than females (Table 2). Eventhought strain $\mathrm{B}$ (Table 3 ) gain higher as a response to protein intake, it does not mean that this strain was more efficient compared to strain A and C.

In $\mathrm{H}$ and $\mathrm{L}$ dietary proteins (Table 3 ), the females of strains $\mathrm{A}$ and $\mathrm{C}$ have better response in $\mathrm{L}$ protein levels, whilst the males of strain $\mathrm{A}$ and $\mathrm{C}$ have better response in $\mathrm{H}$ protein level. Combined with their overall lower protein retention efficiency on the high protein and free choice dietary regimens (Table5), suggesting that protein requirements and utilisation in strain B were significantly different from strains $A$ and C. There was further an indication of strain differences when evaluating the relationships between the carcass components of moisture, fat and protein. The moisture: protein ratios were 2.51, 2.65 and 2.58 in strains $\mathrm{A}, \mathrm{B}$ and $\mathrm{C}$ respectively. This means that strain B had both higher moisture and fat proportions than the two other strains, although the fat difference was small and not significant (Table 4).

Significant differences in protein utilisation have been reported between lines selected divergently for body fatness (McLeod et al., 1988; Geraert et al., 1987; Tomas and Pym, 1995) or for high appetite, feed efficiency or growth rate (Geraert et al, 1987; Tomas et al., 1988; Tesseraud et al., 2000). The genetic diversity between these lines in terms of protein utilisation, is due entirely to the effects of selection, since in each case the lines were derived from the same founder population. The comparison between commercial strains is much more complex, since it includes the effect of the different founder

Table. 3. Performance of Three Different Strains to High (h) or Low (low) Dietary Protein from 21 to 35 Days of Age. Standard Errors in Parenthesis

\begin{tabular}{|c|c|c|c|c|c|}
\hline \multirow{3}{*}{ Sex } & \multirow{3}{*}{ Strain } & \multicolumn{2}{|c|}{ Gain $(\mathrm{g})$} & \multicolumn{2}{|c|}{ Protein Deposition (g) } \\
\hline & & \multicolumn{2}{|c|}{ Diet } & \multicolumn{2}{|c|}{ Diet } \\
\hline & & $\mathrm{H}$ & $\mathrm{L}$ & $\mathrm{H}$ & $\mathrm{L}$ \\
\hline \multirow[t]{3}{*}{ Male } & A & $874(20)$ & $771(18)$ & $136.83(3.71)$ & $112.88(2.85)$ \\
\hline & B & 909 (19) & $832(21)$ & $143.06(3.27)$ & $120.15(3.11)$ \\
\hline & $\mathrm{C}$ & 859 (19) & $770(21)$ & $134.03(3.24)$ & $112.66(3.55)$ \\
\hline \multirow[t]{3}{*}{ Female } & A & $804(26)$ & $766(25)$ & $124.19(4.13)$ & $112.07(4.22)$ \\
\hline & B & $871(21)$ & $805(21)$ & $136.16(3.19)$ & $116.84(3.49)$ \\
\hline & $\mathrm{C}$ & $814(21)$ & $790(24)$ & $125.82(3.16)$ & $114.96(4.05)$ \\
\hline
\end{tabular}


Table 4.The Effect of Strain, Sex and Dietary Regimen on Protein, Fat and Moisture Expressed As A Proportion of The Whole Wet Carcass $(\mathrm{g} / \mathrm{kg})$ in $42 \mathrm{~d}$ Old Chickens

\begin{tabular}{lccc}
\hline & Protein & Fat & Moisture \\
\hline Sex & & & \\
Male & 236.3 & $153.5^{\mathrm{b}}$ & $611.2^{\mathrm{a}}$ \\
Female & 234.7 & $161.1^{\mathrm{a}}$ & $604.4^{\mathrm{b}}$ \\
Strain & & & \\
A & 239.8 & 157.0 & $601.4^{\mathrm{q}}$ \\
B & 230.9 & 159.4 & $613.2^{\mathrm{p}}$ \\
C & 236.0 & 155.7 & $608.8^{\mathrm{pq}}$ \\
Diet & & & \\
Low protein & 232.0 & $165.4^{\mathrm{x}}$ & $604.9^{\mathrm{y}}$ \\
High protein & 239.3 & $146.5^{\mathrm{y}}$ & $615.0^{\mathrm{x}}$ \\
Free choice & 235.2 & $160.1^{\mathrm{x}}$ & $603.5^{\mathrm{y}}$ \\
\hline Men winin
\end{tabular}

Means within columns and series with different superscripts are significantly different $(\mathrm{P}<0.05)$.

populations in the different parental lines and the effect of selection within the lines.

In regard to the latter comparisons of high and low fat lines, McLeod et al. (1988), Geraert et al. (1987) and Tesseraud et al. (2000) found a higher gross efficiency of protein retention in the lean lines. These line differences were due to differences in the partition of retained energy between fat and protein deposition. Thus, selection for food utilisation efficiency, but not selection for leanness, would appear to improve the net efficiency of protein utilisation through a reduction in protein breakdown rate. Furthermore, Pym (2005) observed that improving of nutrient utilization due to the increasing of the capacity of chickens to meet nutrient requirements on diet was vary.

The high consumption of the summit diet in free choice fed by the B strain males was reflected in a low PRE which suggested an inability of the strain to effectively utilise the additional protein consumed. It is not clear as to what may have stimulated intake of the summit diet by this line, but protein requirements would not appear to be implicated.

The effect of strain, sex and dietary regimen on body composition of the chickens at 42 days, is given in Table 4. Females were fatter than males $(\mathrm{P}<0.05)$ and chickens given the high protein dietary regimen contained less fat than those receiving the two other regimens $(\mathrm{P}<0.05)$. Differences in moisture generally reflected differences in fat, but strain $B$ had higher body moisture than strain A. This was unexpected due to their higher non significant body fat.
Considering the genetic factors involved, it seems that the limitation of growth compensation is due to the failure of daily lean meat deposition and in fact, is dependent on genetic potential (Rosa et al., 2001-a; Rosa et al, b). This is supported by data on Table 5 that gain and protein deposition shown by PRE values were higher in high protein concentration for the males of strain A and C. However, for strain B, it would be more desirable to feed low levels of protein due to the difference between the high and low was little.

However, the current study failed to measure protein turnover due to the storage of excreta at room temperature for the three days prior to collection and subsequent storage at $-20^{\circ} \mathrm{C}$, and analysis of the samples revealed exceedingly low levels of 3-methyl histidine, which rendered the comparisons meaningless. The rate of breakdown of 3-methyl histidine in the excreta at room temperature, due no doubt to bacterial activity, was very high and suggests frequent collection and immediate storage at $-20^{\circ} \mathrm{C}$ to minimise this loss.

\section{CONCLUSIONS}

There are differences in response to protein utilization efficiency due to strains. Strain A and C apparently had much higher response in gain in high protein diet by showing better gain and protein deposition whilst strain B would be more advantageous to low protein diet. Involvement of genetic controls as the selection effect seems to 
Table 5. Protein Retention Efficiency (PRE) in The Body, Expressed As A Proportion (\%) of Protein Intake in The Two Sexes of The Three Strains Given The Three Dietary Regimens. Standard Errors in Parenthesis

\begin{tabular}{lccccc}
\hline \multicolumn{1}{c}{ Dietary regimen } & Strain & Male & Female & $\begin{array}{c}\text { Mean for } \\
\text { Diets }\end{array}$ & $\begin{array}{c}\text { Mean for } \\
\text { Strains }\end{array}$ \\
\hline Low protein & A & $46.3(2.1)$ & $36.0(6.0)$ & $42.6(1.5)$ & $44.5(1.5)$ \\
& B & $46.4(5.2)$ & $38.5(3.1)$ & & $41.3(2.1)$ \\
High protein & C & $47.0(3.5)$ & $41.6(2.0)$ & & $46.4(1.5)$ \\
& A & $52.2(2.1)$ & $44.0(1.9)$ & $48.1(1.3)$ & \\
Free choice & B & $46.2(7.3)$ & $43.1(2.3)$ & & \\
& C & $57.7(3.8)$ & $45.6(2.5)$ & & \\
& A & $43.5(6.6)$ & $46.3(3.2)$ & $41.7(2.2)$ & \\
& B & $37.3(5.4)$ & $36.6(7.6)$ & & \\
\hline
\end{tabular}

increase the capacity of chickens to improve nutrient utilization.

\section{ACKNOWLEDGEMENT}

This experimental work presented in this paper was conducted during $\mathrm{PhD}$ studies by the Author with financial support from Australian Sponsored Training Scholarship (ASTAS) The experiments were undertaken at the Queensland Poultry Research and Development Centre, Alexandra Hills and/or the University of Queensland Veterinary Science Farm, Pinjarra Hills.

\section{REFERENCES}

Bastianelli, D. M. Quentin, I. Bouvarel, C. Relandeau, P. Lescoat, M. Picard and S. Tesseraud. 2007. Early lysine deficiency in young broiler chicks. Animal , 1: Page 587-594

Buttery, P. J. 1981. Protein turnover in animals. Trop. Anim. Prod., 6:3: 204-211

Emmans, G.C. 1987. Growth, body composition and feed intake. World's Poult. Sci. J. 47: 208-227. Farrell, D. J. 1974. Effects of dietary energy concentration on utilisation of energy by broiler chickens on body composition determined from carcass analysis and predicted using tritium. Br. Poult. Sci.15: 25-41

Geraert, P. A., MacLeod, M.G., Jewitt, T.R. and J. Anderson. 1987. Energy and nitrogen metabolism in genetically fat and lean chickens. Proc. Nutr. Soc. 46: 34A

Gous, R. M. and T. R. Morris. 1985. Evaluation of a diet dilution technique for measuring the response of broiler chickens to increasing concentrations of lysine. Br. Poult. Sci. 26: 147-161

Hayashi, K., Y. Tomita, Y. Maeda, Y. Shinagawa, K. Inoue and T. Hashizume. 1985. The rate of degradation of myofibrillar proteins of skeletal muscle in broiler and layer chickens estimated by $\mathrm{N}^{\lambda}$-methylhistidine in excreta. Br. J. Nutr. 54: $157-163$

Huyghebaerts, G. and M. Pack. 1996. Effects of dietary protein content, addition of nonessential amino acids and dietary methionine to cystine balance on responses to dietary sulphurcontaining amino acids in broilers. Br. Poult. Sci. 37: 623-639

Kang, C.W., M. L. Sunde and R.W. Swick. $1985 .$. Growth and protein turnover in the skeletal muscles of broiler chicks. Poult. Sci. 64: 370379

Kaps, M and W. Lamberson. 2004. Biostatistics for Animal Science. CABI Publishing, Wallingford,UK.

McLeod, M. G., C.C. Whitehead, H.D. Griffin and T. R. Jewitt. 1988. Energy and nitrogen retention and loss in broiler chickens genetically selected for leanness and fatness. Br. Poult. Sci. 29: 285292 
Nieto, R., Prieto, C., I. Fernandez-Figares and J. F. Aguilera. 1995. Effect of dietary protein quality on energy metabolism in growing chickens. Br. J. Nutr. 74: 163-172

Ojano-Dirain , C. P. and P.W. Waldroup. 2002. Protein and amino acid needs of broilers inwarm weather: A review . Int. J. of Poult. Sci. 1(4) : 40-46

Plumstead, P. W., H. Romero-Sanchez, N. D. Paton, J. W. Spears and J. Brake. 2007. Effects of dietary metabolizable energy and protein on early growth Responses of Broilers to Dietary Lysine. Poult. Sci. 86:2639-2648

Pym, R, A. E. 2005. Genetic aspects of food intake and food utilization efficiency for growth in chickens. Proceeding of the Australian Poultry Symposium. 17 th Annual. Poultry Science Symposium, Sydney New South Wales, 7-9 February, 2005. P 153-162

Pym, R. A. E. and A. J. Solvyns.1979. Selection for food conversion in broilers: body composition of birds selected for increased body weight, gain, food consumption and food conversion ratio. $\mathrm{Br}$. Poult. Sci. 20: 87-97

Rosa, A.P., G.M. Pesti, H. M. Edwards, Jr., and R. I. Bakalli 2001-a Threonine requirements of different broiler genotypes. Poult. Sci. 80: 17101717

Rosa, A. P., G.M. Pesti, H. M. Edwards, Jr., and R. Bakalli 2001-b. Tryptophan requirements of different broiler genotypes . Poult. Sci. 80: 17181722

SAS Institute Inc. 1996. SAS User's Guide: Statistics. Version 6.12. SAS Institute Inc., Cary, NC

Sterling, K. G., G. M. Pesti and R. I. Bakalli. 2003. Performance of broiler chicks fed various levels of dietary lysine and crude protein. Poult. Sci., 82:1939-1947

Sterling, K.G., G.M. Pesti and R. I. Bakalli. 2006. Performance of different broiler genotypes fed diets with varying levels of dietary crude protein and lysine. Poult. Sci, 85:1045-1054

Sunde, M.L., Swick, R.W. and C.W. Kang. 1984. Protein degradation: An important consideration. Poult. Sci. 63: 2055-2061

Surisdiarto and D. J. Farrell. 1991. The relationship between dietary crude protein and dietary lysine requirement by broiler chicks on diets with and without the "Ideal amino acids balance". Poult. Sci. 70: 830-836

Tesseraud, S., A. M. Chagneau, and J. Grizard. 2000. Muscle protein turnover during early development in chickens divergently selected for growth rate. Poult. Sci. 79:1465-1471

Tomas , F. M. and R. A. E. Pym. 1995.. Muscle protein turnover and growth. Archiv für . Geflügel-Kunde. Supplement 1: 23-24

Tomas, F. M., L. M. Jones and R. A. E. Pym . 1988. Rates of muscle protein breakdown in chickens selected for increased growth rate, food consumption or efficiency of food utilisation as assessed by $\mathrm{N}^{\lambda}$-methylhistidine excretion. $\mathrm{Br}$. Poult. Sci. 29: 359-370

Tomas, F. M., R. A.E. Pym and R.I. Johnson. 1991. Muscle protein turnover in chickens selected for increased growth rate, food consumption or efficiency of food utilization. Effects of genotype and relationship to plasma IGF-I and growth hormone. Br. Poult. Sci. 32: 363-376

Urdaneta-Rincon, M. and S. Leeson. 2004. Muscle (pectoralis major) protein turnover in young broiler chickens fed graded levels of lysine and crude protein. Poult. Sci., 83:1897-1903

Young, V. R. and H. N. Munro .1978. $\mathrm{N}^{\lambda_{-}}$ methylhistidine (3-methylhistidine) and muscle protein turnover: an overview. Federation Proceedings. 37: 2291-2300 